\title{
Effects of kelp forests Macrocystis pyrifera on the larval distribution and settlement of red and purple sea urchins Strongylocentrotus franciscanus and $S$. purpuratus
}

\author{
S. C. Schroeter ${ }^{1, *}$, J. D. Dixon ${ }^{1}$, T. A. Ebert ${ }^{1}$, J. V. Rankin ${ }^{2, * *}$ \\ 'Department of Biology, San Diego State University, San Diego, California 92182, USA \\ ${ }^{2}$ Department of Marine Science, University of San Diego, San Diego, California 92110, USA
}

\begin{abstract}
It has often been observed that the abundance of sea urchins is lower inside kelp forests and along their nearshore edges than outside their offshore boundaries. We tested the hypothesis that this distributional pattern is a reflection of settlement patterns by monitoring settlement on artificial surfaces at 3 kelp forests near San Diego, California, USA. We estimated settlement at paired sites under the canopy and outside the offshore edge of the kelp forests and at paired sites located $20 \mathrm{~m}$ outside the canopy near the inshore and offshore boundaries of each kelp forest. There was no evidence of an effect of dense stands of giant kelp on the settlement of purple sea urchins. The results for red sea urchins were ambiguous; in 3 of 7 comparisons, average settlement was higher or observations of higher settlement were more frequent offshore from the kelp forest than elsewhere. Although this could result from different effects on the 2 species, we think it probably was due to accidents of sampling. We conclude that the distributional patterns of purple and red sea urchins relative to kelp forests are unlikely to reflect larval availability or settlement, but are more probably a function of post-settlement events. We qualify our conclusions because of the tremendous temporal variability in the physical and biological factors that can potentially affect the local distribution of sea urchin larvae. The 2 years of this study may be short relative to natural cycles.
\end{abstract}

KEY WORDS: Echinoidea $\cdot$ Kelp - Larval filter hypothesis · Sea urchin · Settlement

\section{INTRODUCTION}

The local distribution and abundance of the many marine benthic organisms that have pelagic larvae may be affected both by settlement and by post-settlement events. Most studies have focused on those factors that account for the variability in growth and survival after settlement (e.g. Hatton 1938, Connell 1961a b, 1970, Frank 1965, Dayton 1971, Paine 1974). This research bias probably has arisen because of the difficulty in documenting both larval supply and initial set-

\footnotetext{
-E-mail: schroete@rohan.sdsu.edu

- Present address: Mt. Carmel High School, 9550 Carmel Mountain Road, San Diego, California 92129, USA
}

tlement for most species. However, work with intertidal barnacles, one of the more tractable groups, has demonstrated that variations in settlement may sometimes be reflected strongly in variations in the distribution and abundance of adults and sometimes not (reviewed in Connell 1985). The conditions under which settlement is a strong determinant of adult patterns have yet to be well defined. Settlement of motile species is more difficult to study, but has been accomplished through the use of artificial settling surfaces (e.g. Loosanoff 1964, Bak 1985, Harrold et al. 1991, Ebert et al. 1994). We adopted this technique to examine the effects of stands of giant kelp Macrocystis pyrifera on the settlement of red and purple sea urchins Strongylocentrotus franciscanus and S. purpu- 
ratus in shallow subtidal habitats in southern California, USA.

Densities of sea urchins are often lower within or along the shoreward edge of dense beds of large canopy-forming brown algae than in nearby open habitats with similar bottom characteristics. This pattern has been noted world-wide (Lawrence 1975) and has been documented with field samples in California (Mattison et al. 1977, Schroeter et al. 1981, Tegner \& Dayton 1981, Dean et al. 1984, Ebeling et al. 1985, Harrold \& Reed 1985, Pearse \& Hines 1987, Rowley 1989), in Nova Scotia, Canada (Lang \& Mann 1976, Bernstein et al. 1981, Raymond \& Scheibling 1987), and in northeastern New Zealand (Andrew \& Choat 1982, 1985). In southern California, purple and red sea urchins often occur in dense aggregations, which include large numbers of small individuals, and which result in depau-

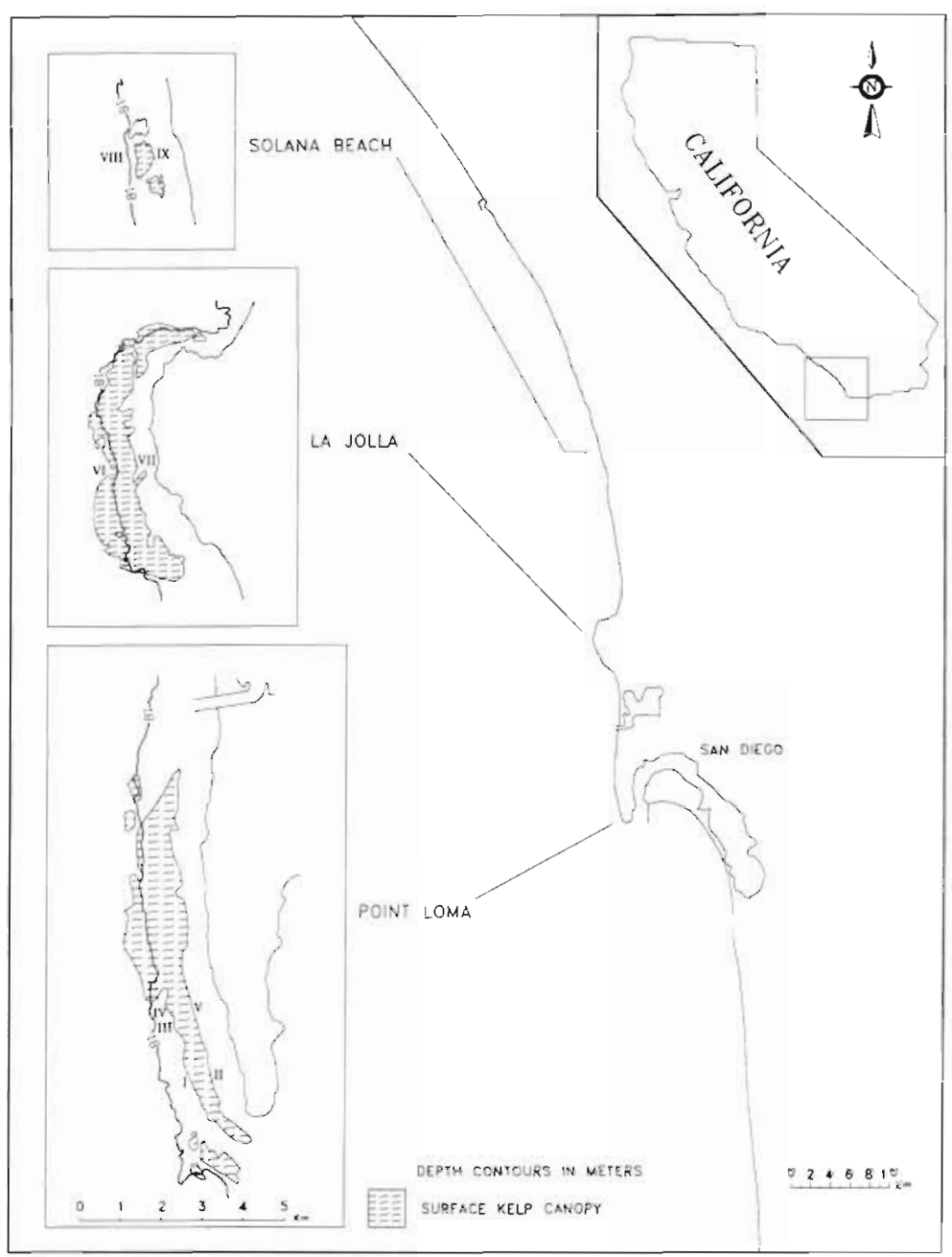

Fig. 1. Location of study sites in the Point Loma, La Jolia, and Solana Beach kelp forests near San Diego, California, USA. Roman numerals identify the stations (map prepared by Kyle Marshall) perate communities of sessile organisms dominated by crustose coralline algae. These urchin-dominated areas or 'barrens' are characteristic of rocky areas offshore from kelp beds but occur rarely within kelp stands. These patterns might result from lower settlement within and inshore from kelp stands, perhaps due to reductions in larval supply or lack of appropriate settlement cues, or from increased losses after settlement due either to higher mortality inside kelp stands or net migration offshore.

We examined the potential importance of larval availability and settlement on the distribution of juvenile and adult sea urchins by estimating settlement at 2 sets of paired sites. We compared the rates of settlement onto artificial substrates placed inside and outside dense giant kelp forests, and we compared settlement along the offshore and nearshore edges of extensive stands of kelp. If the rate of settlement tends to be higher outside the offshore edge of kelp stands, then variability in larval supply or settlement is a likely contributing cause of the local distributional pattern of adult sea urchins. On the other hand, if the rates of settlement along the offshore edge are similar to or lower than rates observed at sites under the canopy or inshore from the kelp bed, then the distributional patterns of larger urchins probably result from post-settlement mortality or movement.

\section{MATERIALS AND METHODS}

Study sites. This study was conducted in the Point Loma, La Jolla, and Solana Beach giant kelp Macrocystis pyrifera forests near San Diego, California (Fig. 1). The seafloor at these sites was mostly exposed, relatively uniform bedrock platform with occasional ledges 0.5 to $2 \mathrm{~m}$ high and patches of broken reef, portions of which had been eroded into boulders and cobbles of various sizes. Important understory algae were Pterygophora californica, Cystoseira osmundacea, Laminaria farlowil, and Eisenia arborea. Strongylocentrotus franciscanus and $S$. purpuratus were common to abundant at each of the study sites and generally several times denser outside the kelp bed than under the canopy. For example, near Stn III in the Point Loma kelp forest (Fig 1), the average abundance (and $95 \%$ confidence interval) of red sea urchins $50 \mathrm{~m}$ outside the 
kelp bed was $12( \pm 4.1) \mathrm{m}^{-2}$ compared to $0.3( \pm 0.3) \mathrm{m}^{-2}$ measured $50 \mathrm{~m}$ inside the kelp bed (S. Schroeter \& J. Dixon unpubl. data). Similarly, for purple sea urchins the densities outside and inside the kelp bed were 16 $( \pm 4.8) \mathrm{m}^{-2}$ and $2.8( \pm 2.8) \mathrm{m}^{-2}$, respectively. Two other species of sea urchins, Lytechinus anamesus and Centrostephanus coronatus, also occur in these kelp forests, but were not observed at our stations during the course of the study. Potential predators included a number of fishes (particularly the sheephead Semicossyphus pulcher), spiny lobster Panulirus interruptus, and several species of seastars (Pycnopodia helianthoides, Asterina miniata, Astrometis sertulifera). In cryptic habitats in both the La Jolla and Point Loma kelp forests, we have found small red sea urchins ( $-5 \mathrm{~mm}$ diameter) with holes in the test that suggested crab predation, perhaps by juvenile Cancer spp.

We established monitoring stations at each kelp forest in an area where there was continuous dense $\left(-1\right.$ plant $\left.10 \mathrm{~m}^{-2}\right)$ surface canopy 500 to $600 \mathrm{~m}$ wide (Fig. 1). Stn I consisted of 3 haphazardly placed crossshelf transects which were perpendicular to the offshore edge of the kelp canopy and spaced about $20 \mathrm{~m}$ apart (Rankin 1993). Along each transect, settlement was monitored at 4 locations ( 2 and $20 \mathrm{~m}$ from the edge of the kelp bed both under the canopy and in the open). Stns III, IV, VI, and VIII were also located along the offshore edge of a kelp bed. At each of these stations, settlement was monitored at a location $20 \mathrm{~m}$ under the canopy and $20 \mathrm{~m}$ offshore from the edge of the canopy. Stns II, V, VII, and IX were each located along the nearshore edge of a kelp bed opposite the offshore stations. At the nearshore stations, settlement was monitored at a location $20 \mathrm{~m}$ outside the canopy. The water depth was about $15 \mathrm{~m}$ at the offshore stations and about $12 \mathrm{~m}$ at the nearshore stations.

Estimating settlement rates. At each station, settlement was monitored using wood-handled scrub brushes with nylon bristles (National Brush Company, Aurora, IL, USA; Ebert et al. 1994). The brushes were $20 \mathrm{~cm}$ long by $6 \mathrm{~cm}$ wide and contained 48 clusters of about 100 bristles, $2.7 \mathrm{~cm}$ long. Each set of 2 brushes was attached to an anchored nylon line and buoyed about $1 \mathrm{~m}$ above the bottom to prevent the bristles from being clogged by sediments resuspended by waves. The scrub brushes were collected approximately weekly (range: 5 to $20 \mathrm{~d}$, mean, $7.5 \mathrm{~d}$ ). The collected brushes were placed in a sonic cleaner, covered with sea water, and vibrated with high-frequency sound for 3 to $5 \mathrm{~min}$ to remove settlers. During sonication, the bristles were gently rubbed by hand. The seawater was then poured through a $0.436 \mathrm{~mm}$ mesh plastic screen, which retains newly settled sea urchins. These recently metamorphosed sea urchins vary from about 0.35 to $0.55 \mathrm{~mm}$ in test diameter (urchins with test diameters smaller than the mesh size of the screen are prevented from passing through by their spines).

All materials caught on the screens were sorted under a dissecting microscope. Recently settled sea urchins were preserved in $75 \%$ ethyl alcohol for later identification to species. Red, purple, and white (Lytechinus anamesus) sea urchins were potential settlers. Red and white sea urchins have from 1 to 3 dorsal pedicellariae, whereas purple urchins have none (Ebert et al. 1994). Examination of sea urchins that were cultured in the laboratory from eggs and sperm confirmed the diagnostic value of dorsal pedicellariae and demonstrated that recently metamorphosed red sea urchins are characteristically more heavily pigmented than white sea urchins.

We confined the sampling for this mensurative experiment to the major settlement periods in 1991 and 1992. Although a few newly settled red and purple sea urchins have been observed during every month of the year, most settlement occurs sometime between about January and August (Harrold et al. 1991, Rankin 1993, Ebert et al. 1994). However, within this potential 'settlement season' the actual period of intense settlement varies markedly from year-to-year. We monitored weekly settlement throughout the year at only 2 stations (III and IV; Ebert et al. 1994). When it was apparent from the observations at those stations that the 1991 settlement period was commencing, we began weekly observations at the rest of the stations. We conducted this experiment from March 28 through May 21, 1991 at Stns I to IX. In 1992, we continued to monitor settlement in and out of the kelp bed at Stns III and IV. Settlement was monitored from January 2 to January 22 and from April 28 through July 22. No samples were collected in February and March because of possible water pollution during that period from a broken sewage pipe. The possible number of weekly observations was 8 in 1991 and 15 in 1992. The potential number of replicates for a given comparison was the number of weekly observations times the number of paired sites. However, samples from a given pair were not used in the analyses if there was no settlement on any of the brushes at the locations being compared. As a result of these cases of all zeros and of occasional missing data due to logistic problems, the actual replication was less (Table 1).

Sampling design. We made 2 types of comparisons to examine the effects of canopy-forming kelp on the settlement of sea urchins. First, we compared settlement under dense canopy to settlement outside the bed. Second, we compared settlement at open sites located offshore and inshore from areas of extensive kelp canopy. For the comparison of settlement inside and outside kelp beds, we used paired locations $20 \mathrm{~m}$ under the canopy and $20 \mathrm{~m}$ offshore from the edge of 
Table 1. Strongylocentrotus franciscanus and S. purpuratus. Number of replicate settlement observations by year, species, and kelp forest for 2 comparisons. During 1991, settlement was monitored at all stations in all 3 kelp forests from March 28 through May 21. During 1992, settlement was monitored at Stns III and IV at the offshore edge of the Point Loma kelp forest during January and from April 28 through July 22

\begin{tabular}{|lcccc|}
\hline $\begin{array}{l}\text { Comparison } \\
\text { Species }\end{array}$ & $\begin{array}{c}\text { Solana Beach } \\
1991\end{array}$ & $\begin{array}{c}\text { La Jolla } \\
1991\end{array}$ & \multicolumn{2}{c|}{ Point Loma } \\
\hline $\begin{array}{l}\text { Inside vs Outside } \\
\quad \text { S. purpuratus }\end{array}$ & 0 & 2 & 1991 & 1992 \\
$\quad \begin{array}{l}\text { S. franciscanus } \\
\text { Inshore vs Offshore }\end{array}$ & 0 & 1 & 5 & 15 \\
$\quad$ S. purpuratus & 6 & 4 & 8 & 4 \\
S. franciscanus & 6 & 1 & 5 & 0 \\
\hline
\end{tabular}

sects at Stn I. The model has 2 main effects position and transect. Position with respect to the edge of the kelp bed is a fixed effect; transect is a random effect

In addition to determining a significance value (the probability of obtaining a difference of the observed magnitude by chance), we examined the power of the tests (the probability of a real difference being judged statistically significant). If there is no real difference between the locations being compared, the settlement rates would tend to be similar (unless there were extreme sampling error) and the power to detect a difference of the magnitude actually observed generally would be very low. Therefore, this calcula-

the kelp at Stns I, III, IV, and VI. Stn VIII at Solana Beach was not used in this analysis because during the study there was a natural loss of kelp and thinning of the canopy, especially along the offshore edge of the bed. For the comparison of settlement inshore and offshore of kelp beds, the following pairs were used: Stn. I versus Stn II; the average of Stns III and IV (which were only about $100 \mathrm{~m}$ apart) versus Stn V; Stn VI versus Stn VII, and Stn VIII versus Stn IX. The average of the 3 transects at Stn I was used in the various paired comparisons where the replication was based on weekly settlement at each station. In addition, an analysis of variance was done using only data from Stn I to examine small-scale patterns

For each set of paired observations, the variate used was the difference in weekly settlement (mean of 2 paired brushes) at the 2 sample sites being compared. These replicate observations were used in a 1-tailed $t$-test of the hypothesis that the average difference was not greater than zero (i.e. that settlement was not greater outside than inside the kelp bed boundary, or that settlement was not greater offshore than inshore from kelp forests). We also conducted non-parametric analyses of the effects of kelp on settlement. We tallied the number of periods during which settlement was higher inside the kelp bed and the number during which settlement was higher outside the bed. The null hypothesis that the ratio of the 2 cases did not differ from 1:1 was tested with a binomial test. The alternative hypothesis is that the proportion of observations where settlement was higher offshore was greater than 0.5. A similar analysis was done for comparisons of settlement between sites inshore and offshore of the kelp bed. Separate analyses were done for purple and red sea urchins.

The effects of distance from the edge of the canopy and small-scale spatial variability on settlement were examined with a factorial analysis of variance, using observations from all 4 sites along each of the 3 tran- tion is of little value. A more useful approach is to calculate the power to detect a particular difference that is considered ecologically significant. We chose a slightly different tack. We calculated the difference required to achieve a power of $0.80(\alpha=0.05)$ for each $t$-test. This difference is presented both as an absolute value and as the percentage reduction from the actual average settlement observed outside the offshore edge of the kelp beds. Similarly, in the case of the binomial tests, we present the proportion of observations of higher offshore settlement for each comparison that would be required for the test to have a power of 0.80 (Cohen 1988). Since frequencies are discrete, the values for $\alpha(0.05)$ and power $(0.80)$ are approximate. Where more than 2 population means are being compared by an analysis of variance, the effect size is defined as the ratio of the standard deviation of the mean of the main effect over the within-population standard deviation, which is assumed to be the same for each level of the main effect (Cohen 1988). For each main effect, we calculated the effect size necessary to yield a power of 0.80 with $\alpha=0.05$.

\section{RESULTS}

There was no evidence of lower rates of settlement of either purple or red sea urchins at sites located under dense kelp canopy compared to offshore sites. The average difference between paired sites outside and inside the canopy at the La Jolla and Point Loma kelp beds did not differ significantly from zero for either species (Table 2A, Fig. 2). Although the number of newly settled sea urchins on each brush was small (Strongylocentrotus purpuratus: 0 to $10 ; S$. franciscanus: 0 to 9), an approximate halving of the average levels of settlement observed at sites offshore of the kelp canopy would result in power of 0.80 for purple sea urchins (Table 2A). For red sea urchins a decrease 
Table 2. Strongylocentrotus franciscanus and S. purpuratus. Comparison of settlement inside and outside the offshore edge of the La Jolla and Point Loma kelp beds. (A) Test of the null hypothesis that the rate of settlement on artificial substrates does not differ outside and inside giant kelp forests. The variate is the number of newly settled sea urchins per brush per week. Delta $=(n u m-$ ber per brush outside) - (number per brush inside). The null hypothesis is that the average delta $=0$. The delta required for a power of $0.80(\alpha=0.05)$ is expressed in 2 ways: the difference between stations in the Number per brush per week and this difference as a percentage Reduction from the mean settlement rate actually observed at the stations outside the kelp forests. (B) Binomial test of the null hypothesis that the proportion of occurrences of higher settlement outside the kelp bed does not differ from 0.5. The probability (p) of falsely rejecting the null hypothesis and the real proportion of occurrences of higher settlement outside the kelp bed for which the test would have a power of 0.80 are also tabulated

\begin{tabular}{|c|c|c|c|c|c|c|c|c|}
\hline \multirow{2}{*}{$\begin{array}{l}\text { (A) } \\
\text { Species }\end{array}$} & \multirow[b]{2}{*}{ N } & \multirow[b]{2}{*}{$\begin{array}{l}\text { Mean rate } \\
\text { outside }\end{array}$} & \multirow[b]{2}{*}{$\begin{array}{l}\text { Mean rate } \\
\text { inside }\end{array}$} & \multirow[b]{2}{*}{$\begin{array}{l}\text { Mean } \\
\text { delta }\end{array}$} & \multirow[b]{2}{*}{$t$-value } & \multirow[b]{2}{*}{$\mathrm{p}>t$} & \multirow{2}{*}{\multicolumn{2}{|c|}{ Delta for power of 0.80}} \\
\hline & & & & & & & & \\
\hline S. purpuratus & 30 & & 0.75 & 0.07 & 0.41 & 0.69 & 0.44 & $54 \%$ \\
\hline S. iranciscanus & 9 & & 0.19 & 0.21 & 1.69 & 0.13 & 0.33 & $83 \%$ \\
\hline \multicolumn{9}{|l|}{ (B) } \\
\hline Species & $\begin{array}{c}\text { Number higher } \\
\text { outside }\end{array}$ & & $\begin{array}{l}\text { lumber higher } \\
\text { inside }\end{array}$ & & & $\mathrm{p}$ & $\begin{array}{c}\mathrm{Pr} \\
\mathrm{p}\end{array}$ & $\begin{array}{l}\text { ortion for } \\
\mathrm{er} \approx 0.80\end{array}$ \\
\hline S. purpuratus & 13 & & 13 & & & 0.58 & & 0.75 \\
\hline S. franciscanus & 7 & & 1 & & & 0.04 & & 0.90 \\
\hline
\end{tabular}

of $83 \%$ would be necessary to yield a $t$-test with equivalent power. For purple sea urchins, there was no evidence that the rate of settlement was higher outside the kelp bed than under the canopy more than $50 \%$ of the time (Table 2B). With expectations of a reduction in settlement around 75 to $90 \%$ of the time, the power of the test would be about 0.80 . Red sea urchins settled more abundantly outside the kelp bed on 7 of 8 occasions, which is significantly different from expectation under the null hypothesis (Table 2B). The finer-scaled observations of settlement patterns at Stn I revealed no differences in settlement patterns of either purple or red sea urchins relative to the edge of the kelp bed (Table 3, Fig 3). If the standard deviation of the mean of the main effect populations was about $30 \%$ of the within-population standard deviation, the F-test would yield a power of 0.80 (Table $3 \mathrm{~b}$ ). This is probably a medium effect size (cf. Cohen 1988).

The results of the offshore versus nearshore comparisons were more complicated (Table 4, Fig. 4). We first made the comparisons using data from all 3 kelp forests. However, because the Solana Beach kelp forest was smaller and more fragmented than the other 2 and had thinned during the course of our study, we repeated the analysis with the Solana Beach data excluded. The average rate of settlement of both purple and red sea urchins was higher inshore from the kelp bed at Solana Beach than offshore (Fig. 4). A similar pattern was observed for purple urchins at La Jolla. On the other hand, there was no settlement of red urchins at the sites inshore from the La Jolla and Point Loma kelp beds. As a result of these locational differences in settlement patterns, the results of the analyses

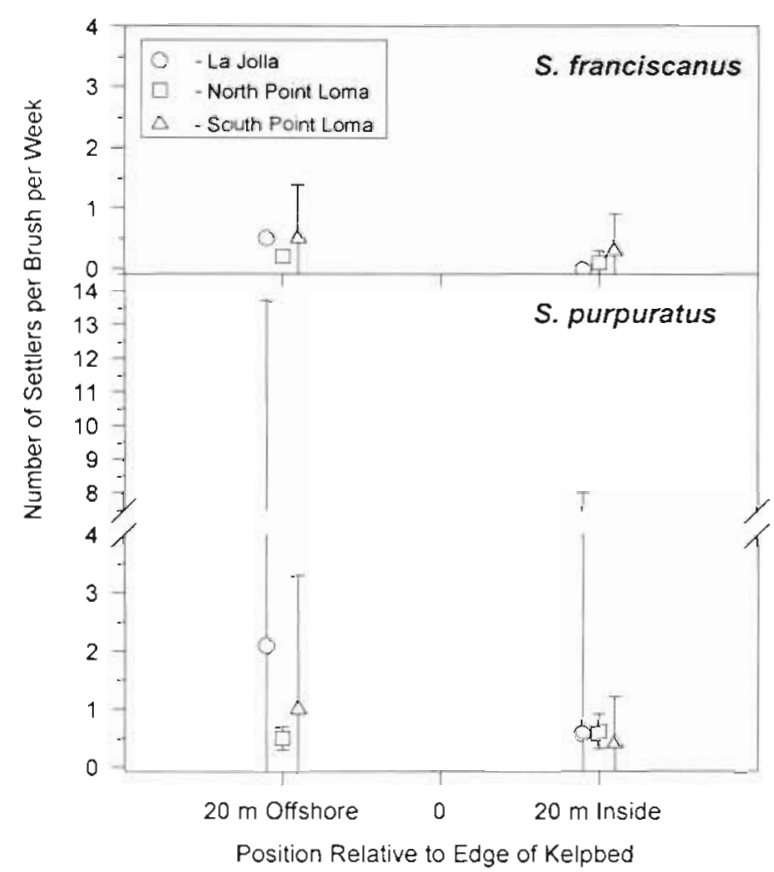

Fig. 2. Strongylocentrotus franciscanus and S. purpuratus. Average number ( $\pm 95 \%$ confidence interval) of recently settled red and purple sea urchins at sites $20 \mathrm{~m}$ offshore and $20 \mathrm{~m}$ inside the canopy of the Point Loma and La Jolla kelp beds. Point Loma North stations are Stns III and IV. Stn I is Point Loma South

using all the data differed from the results obtained when the Solana Beach observations were excluded. In neither case was there any evidence of an effect of giant kelp stands on the settlement rate of purple sea 
Table 3. Strongylocentrotus franciscanus and S. purpuratus. ANOVA of red and purple sea urchin settlement relative to the offshore boundary of the Point Loma kelp forest at Stn I. The Position $\times$ Transect interaction was not statistically significant $(p>0.25)$, so the interaction sum of squares was combined with the residual. The dependent variable is the mean number of red or purple sea urchins settling per brush per week at each of 4 positions along 3 transects. There were 48 observations for purple urchins and 44 observations for red urchins. The effect size (ES) necessary to yield a power of $0.80(\alpha=0.05)$ for the F-test is tabulated. The ES is the ratio of the standard deviation of the mean of the main effect to the within-population standard deviation

\begin{tabular}{|lrrrrrr|}
\hline Source & df & SS & MS & $F$ & $p>F$ & $\begin{array}{c}\text { ES for power } \\
\text { of } 0.80\end{array}$ \\
\hline $\begin{array}{l}\text { S. purpuratus } \\
\text { Position }\end{array}$ & 3 & 3.08 & 1.03 & 1.05 & 0.38 & 0.29 \\
$\quad$ Transect & 2 & 0.17 & 0.08 & 0.08 & 0.92 & 0.32 \\
$\begin{array}{l}\text { Residual } \\
\text { Corrected total }\end{array}$ & 42 & 41.38 & 0.98 & & & \\
$\begin{array}{l}\text { S. franciscanus } \\
\text { Position }\end{array}$ & 3 & 0.25 & 0.08 & 0.21 & 0.89 & 0.30 \\
$\quad \begin{array}{l}\text { Transect } \\
\text { Residual }\end{array}$ & 2 & 0.26 & 0.13 & 0.33 & 0.72 & 0.33 \\
$\quad$ Corrected total & 43 & 14.73 & 0.39 & & & \\
\hline
\end{tabular}

urchins (Table 4A). Similarly, there was no evidence that their rate of settlement was higher offshore more than half the time (Table 4B). The results for red sea urchins were less clear cut. When all the data were used in the analysis, the average settlement was slightly greater at the inshore stations and, hence, there was no evidence for a reduction in settlement rate caused by the presence of giant kelp stands (Table 4). However, since there was never any settlement at nearshore La Jolla or Point Loma stations, the differences using those data were highly significant (Table 4A) and the settlement rate was higher offshore $100 \%$ of the time (Table 4B). When all the data were used, the difference between sites required to yield a t-test with $80 \%$ power was twice as large as the observed settlement at the offshore stations for both species, which is meaningless in terms of a reduction in settlement. This result reflects the fact that the observed aver-

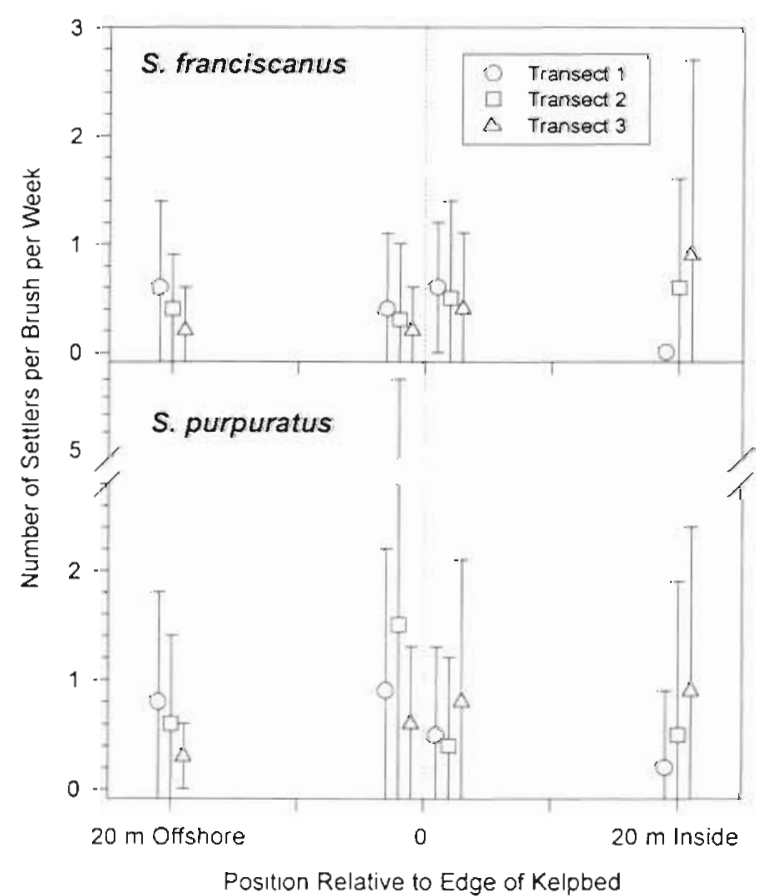

Fig. 3. Strongylocentrotus franciscanus and $S$. purpuratus. Average number $( \pm 95 \%$ confidence interval) of recently settled red and purple sea urchins at 4 positions relative to the edge of the Point Loma (Stn I) kelp bed: $20 \mathrm{~m}$ and $2 \mathrm{~m}$ offshore from the edge of the kelp bed and $20 \mathrm{~m}$ and $2 \mathrm{~m}$ inside the bed under the canopy. Observations are from 3 replicate transects spaced about $20 \mathrm{~m}$ apart

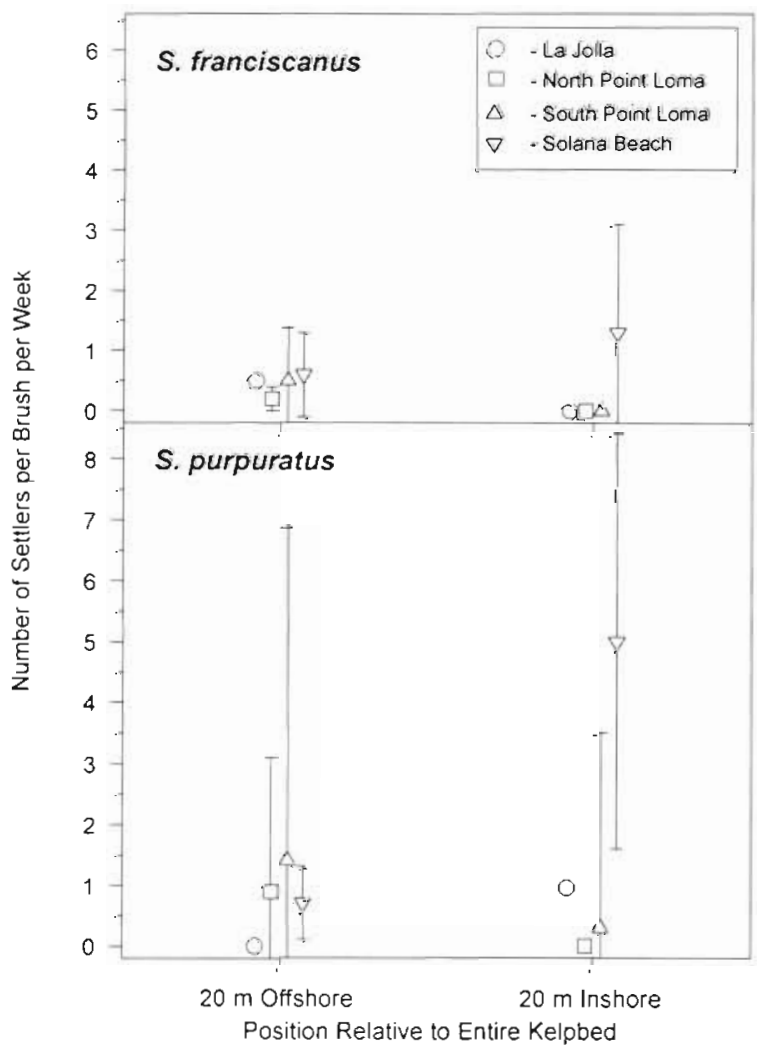

Fig. 4. Strongylocentrotus franciscanus and $S$. purpuratus Average number $( \pm 95 \%$ confidence interval) of recently settled red and purple sea urchins at sites $20 \mathrm{~m}$ offshore and $20 \mathrm{~m}$ inshore of the Point Loma, La Jolla, and Solana Beach kelp beds. Point Loma North stations are Stns III, IV, and V Point Loma South stations are Stns I and II 
Table 4. Strongylocentrotus franciscanus and S. purpuratus. Comparison of settlement inshore and of fshore of the Solana Beach (S.B.), La Jolla, and Point Loma kelp forests. (A) Test of the null hypothesis that the rate of settlement on artificial substrates does not differ at sites offshore and inshore from giant kelp forests. The variate is the number of newly settled sea urchins per brush per week. Delta $=$ (number per brush offshore) - (number per brush inshore). The null hypothesis is that the average delta $=0$. The delta required for a power of $0.80(\alpha=0.05)$ is expressed in 2 ways: the difference between stations in the Number per brush per week and this difference as a percentage Reduction from the mean settlement rate actually observed at the stations outside the kelp forests. (B) Binomial test of the null hypothesis that the proportion of occurrences of higher settlement offshore from the kelp bed does not differ from 0.5 . The probability (p) of falsely rejecting the null hypothesis and the real proportion of occurrences of higher settlement of fshore from the kelp bed for which the test would have a power of 0.80 are also tabulated

\begin{tabular}{|c|c|c|c|c|c|c|c|c|}
\hline \multicolumn{9}{|l|}{ (A) } \\
\hline \multirow{2}{*}{$\begin{array}{l}\text { Species } \\
\text { Data base }\end{array}$} & \multirow[t]{2}{*}{$d f$} & \multirow{2}{*}{$\begin{array}{l}\text { Mean rate } \\
\text { outside }\end{array}$} & \multirow{2}{*}{$\begin{array}{l}\text { Mean rate } \\
\text { inside }\end{array}$} & \multirow{2}{*}{$\begin{array}{l}\text { Mean } \\
\text { delta }\end{array}$} & \multirow[t]{2}{*}{$t$-value } & \multirow[t]{2}{*}{$p>t$} & \multicolumn{2}{|c|}{ Delta for power of 0.80} \\
\hline & & & & & & & Number & Reduction \\
\hline \multicolumn{9}{|l|}{ S. purpuratus } \\
\hline All data & 17 & 0.86 & 2.14 & -1.27 & -1.86 & 0.08 & 1.78 & - \\
\hline S.B. excluded & 11 & 0.96 & 0.69 & 0.26 & 0.76 & 0.46 & 0.93 & $97 \%$ \\
\hline \multicolumn{9}{|l|}{ S. franciscanus } \\
\hline All data & 11 & 0.50 & 0.66 & -0.16 & -0.39 & 0.71 & 1.06 & - \\
\hline S.B. excluded & 5 & 0.42 & 0.00 & 0.42 & 3.83 & 0.01 & 0.32 & $77 \%$ \\
\hline \multicolumn{9}{|l|}{ (B) } \\
\hline $\begin{array}{l}\text { Species } \\
\text { Data base }\end{array}$ & $\begin{array}{c}\text { Number higher } \\
\text { outside }\end{array}$ & & $\begin{array}{l}\text { Number higher } \\
\text { inside }\end{array}$ & & & $\mathrm{p}$ & & $\begin{array}{l}\text { Dortion for } \\
\text { ver }=0.80\end{array}$ \\
\hline \multicolumn{9}{|l|}{ S. purpuratus } \\
\hline All data & 7 & & 11 & & & 0.88 & & 0.80 \\
\hline S.B. excluded & 7 & & 5 & & & 0.39 & & 0.80 \\
\hline \multicolumn{9}{|l|}{ S. franciscanus } \\
\hline All data & 8 & & 4 & & & 0.19 & & 0.80 \\
\hline S.B. excluded & 6 & & 0 & & & 0.02 & & $>0.90$ \\
\hline
\end{tabular}

age settlement was actually higher nearshore than offshore for both species. With the Solana Beach data excluded, the power of the t-test was low, with very large reductions in settlement required to provide a test with $80 \%$ power (Table $4 \mathrm{~A}$ ). The power of the binomial test was 0.80 given higher average settlement at the offshore sites about $80 \%$ of the time (Table $4 \mathrm{~B}$ ).

\section{DISCUSSION}

Purple sea urchins settled onto artificial substrates at similar rates regardless of the position of those substrates relative to giant kelp forests. There was no statistical evidence of a reduction of settlement due to the presence of giant kelp, and the power of the tests to detect realistic reductions was generally high. The results for red sea urchins were ambiguous. Settlement was significantly greater offshore than inshore from the kelp forests for one set of observations and, although there was no evidence of a decreased average rate of settlement under the kelp canopy, higher settlement occurred more frequently outside the kelp bed. The difference in results for red and purple sea urchins might reflect real differences in the effect of kelp beds on the settlement of the 2 species, or it might result from sampling error. Although the question can not be resolved here, we suspect the latter, both because of the low and variable rates of settlement during the course of our observations and because of the striking similarities in the development and larval behavior of the 2 species (Cameron \& Schroeter 1980 , Strathmann 1987).

We conclude that there were no significant differences in the availability of competent sea urchin larvae at the various sites in and around the kelp forests where our observations were made. Dense stands of giant kelp do not form a physical barrier to larvae. When a current encounters a kelp forest most of the water is diverted around the kelp and that which enters the kelp slows to about one-third of the outside speed (Jackson \& Winant 1983). At Point Loma, the net longshore flow in the kelp forest varied from less than 1 to around $3 \mathrm{~km} \mathrm{~d}^{-1}$ and cross-shelf semi-diurnal movements were in the neighborhood of 0.5 to $1 \mathrm{~km}$ every $12 \mathrm{~h}$ (Jackson \& Winant 1983). Although the stagnant flow within the kelp forest may have important biological implications, it is unlikely to significantly affect the local availability of long-lived larvae such as those of sea urchins which probably spend 30 to $90 \mathrm{~d}$ in the plankton (Strathmann 1987).

Indirect effects of kelp on larval supply appear more probable than direct effects. Bernstein \& Jung (1979) found that the epiphytic bryozoan Membranipora 
membranacea was often most abundant along the outer margins of the Point Loma kelp forest and suggested that larval abundance might decrease with distance from the offshore edge of the bed because of losses due to settlement as appropriate substrates were encountered and because of losses due to predation by planktivorous fishes living in the kelp canopy. Both of these mechanisms could be facilitated by the effect of kelp on currents. The slowing of the water would increase both the time available for natural settling behavior to reduce larval concentrations and the time of exposure to planktivorous fishes. Bray (1981) provided evidence for the latter mechanism in kelp forests near Santa Barbara, California, where large aggregations of the temperate damselfish, Chromis punctipinnus, form at the upstream edges of the kelp beds. Predation by $C$. punctipinnus significantly reduced the down-current densities of zooplankton. Similarly, work with barnacles in central California suggests that, as they pass through kelp forests on their way to the shore, late-stage barnacle larvae are eaten by planktivorous juvenile rockfish Sebastes spp. that live in the kelp canopy. Gaines \& Roughgarden (1987) found an inverse relationship between the settlement and recruitment of barnacles within the rocky intertidal zone and the regional abundance of juvenile rockfish. Reductions of larval abundance by filter-feeding epiphytes living on algae such as Macrocystis pyrifera has also been proposed to explain the lower rates of recruitment of sea urchins within algal stands (Pearse et al. 1970). Although these may be important factors, they evidently were not operating during the 2 years of our observations.

Other factors may operate directly on settlement and could produce the abserved patterns in adult distribution despite similarities of larval supply. The generally observed lower abundance of red and purple urchin recruits under canopy and near the inshore boundaries of kelp beds could result from larval selectivity and a general absence of suitable substrates. This seems unlikely on 2 counts. First, the rocky substrates at the various settlement sites were very similar and the edges of kelp forests commonly move 10 s to 100 s of meters cross-shelf from year-to-year. Second, although red and purple sea urchin larvae show some selectivity for coralline algae (Cameron \& Schroeter 1980, Rowley 1989), the presence of ubiquitous bacterial films seems to be the major settlement cue (Cameron \& Schroeter 1980). Nevertheless, without knowledge of the relationship of settlement on artificial substrates to settlement in natural habitats, conclusions regarding the effects of kelp on settlement must be qualified. However, we have made 2 observations that give us confidence that the variate we are measuring is an index of natural settlement. First, during $4 \mathrm{wk}$ in spring 1991 . we compared settlement on beach cobbles placed on the seafloor with settlement on brushes suspended $1 \mathrm{~m}$ above and there was a positive linear relationship between total counts on the 2 substrates (Ebert et al. 1991). Second, we compared settlement on brushes with the later density of small sea urchins in natural habitats in the Point Cabrillo Marine Reserve in Mendocino County, Califormia. There was very little settlement on brushes in northern California in 1990 and 1991 (Ebert et al. 1994) and sea urchins less than $20 \mathrm{~mm}$ in test diameter were rare on natural substrates near our settlement station during benthic surveys in 1990-1992 (P. Kalvass unpubl. data). Following substantial settlement on brushes in 1992 and 1993, a significant increase in the density of little sea urchins was observed during the next benthic survey which was in 1994. Therefore, we think the results reported here also suggest that the presence of kelp had no effect on settlement in natural habitats.

Rowley (1989) obtained a similar result. He found no difference in recruitment, as measured by the combined abundance of 5 to $17 \mathrm{~d}$ old red and purple sea urchins on hatuidi rocks, in a sea urcnin-dominated area and in a small kelp stand some 10 s of meters away. He noted that his results were based on a single settlement event in a low density kelp forest, and might not be typical. However, the results of our study at 3 large, generally dense kelp forests for 1 or 2 settlement seasons tend to substantiate his findings.

How do these results compare to the findings that kelp forests reduce bryozoan (Bernstein \& Jung 1979) or barnacle (Gaines \& Roughgarden 1987, Roughgarden et al. 1988) settlement? In fact, Roughgarden et al. (1988) found that the kelp bed sometimes had little or no effect on barnacle settlement. The negative effect of kelp beds was directly correlated with the regional abundance of juvenile rockfish, which prey on barnacle larvae. If predation on larvae is the main mechanism by which kelp beds affect settlement, one could argue that our experiments were conducted during a 2 yr period when such biological effects were nil. The only way to conclusively address this idea is to make appropriate observations over many settlement seasons or during periods when important planktivores are known to be abundant. To date, however, there is no evidence to support the hypothesis that large kelp beds reduce settlement of sea urchins under the canopy or near the inshore boundaries by reducing larval supply.

Acknowledgements. This work was supported by the California Department of Fish and Game through the Director's Sea Urchin Advisory Committee, the Pacific States Marine Fisheries Commission, and California Sea Grant. Kelco Corporation generously provided logistic support. Members of their manne biology group tended collectors at 2 stations and con- 
ducted benthic surveys at Point Loma in 1991. P. Kalvass generously provided the results of benthic surveys conducted by the California Department of Fish and Game, Ft. Bragg, California. This study could not have been completed without the help of many friends and colleagues. We were assisted in the field by $G$. Birch, S. Cassell, I Delle. H. Dorr, T Hazel, D. McKay, T Miles, K. Ulrich, M. Otjens, D. Glantz, and $R$. McPeak. Much of the laboratory processing of samples was done by D. Medeiros and J. Wolf. P. Leahy and A. Cameron provided recently metamorphosed sea urchins which they cultured at the Californa Institute of Technology's Kerckhoff Marne Laboratory. The manuscript benefited greatly from the critical comments of J. Connell, J. Kastendiek, D. Reed, and R. Rowley. A portion of this work was the basis for the degree of Master of Science awarded by the University of San Diego to J.R., who thanks his thesis advisor, R. Casey, for support and encouragement.

\section{LITERATURE CITED}

Andrew NL, Choat $\mathrm{JH}$ (1982) The influence of predation and conspecific adults on the abundance of juvenile Evechinus chloroticus (Echinoidea: Echinometridae). Oecologia 54: $80-87$

Andrew NL, Choat JH (1985) Habitat related differences in the survivorship and growth of juvenile sea urchins. Mar Ecol Prog Ser 27:155-161

Bak RPM (1985) Recruitment patterns and mass mortality in the sea urchin Diadema antillarum. Proc 5 th int Coral Reef Conf 5:267-272

Bernstein BB, Jung N (1979) Selective pressures and coevolution in a kelp canopy community in southern California. Ecol Monogr 49:335-3.55

Bernstein BB, Williams BE, Mann KH (1981) The role of behaviora] responses to predators in modifying urchins' (Strongylocentrotus droebachiensis) destructive grazing and seasonal foraging patterns. Mar Biol 63:37-49

Bray RN (1981) Influence of water currents and zooplankton densities on daily foraging movements of blacksmith, Chromis punctipinnis, a planktivorous fish. Fish Bull US 78:829-841

Cameron RA, Schroeter SC (1980) Sea urchin recruitment: effect of substrate selection on juvenile distribution. Mar Ecol Prog Ser 2:243-247

Cohen J (1988) Statistical power analysis for the behavioral sciences, 2nd edn. Lawrence Erlbaum Associates, Hillsdale, $\mathrm{NJ}$

Connell JH (1961a) Effects of competition, predation by Thais lapillus and other factors on natural populations of the barnacle Balanus balanoides. Ecol Monogr 31:61-104

Connell JH (1961b) The influence of interspecific competition and other factors on the distribution of the barnacle Chthamalus stellatus. Ecology 42:710-723

Connell JH (1970) A predator-prey system in the marine intertidal region. 1. Balanus glandula and several predatory species of Thais. Ecol Monogr 40:49-78

Connell JH (1985) The consequences of variation in initial settlement vs. post-settlement mortality in rocky intertidal communities. J exp mar Biol Ecol 93:11-45

Dayton PK (1971) Competition, disturbance and community organization: the provision and subsequent utilization of space in a rocky intertidal community. Ecol Monogr 41. $351-389$

Dean TA, Schroeter SC, Dixon JD (1984) Effects of grazing by two species of sea urchins (Strongylocentrotus franciscanus and Lytechinus anamesus) on recruitment and sur- vival of two species of kelp (Macrocystis pyrifera and Pterygophora Californica). Mar Biol 78:301-313

Ebeling AW, Laur DR, Rowley RJ (1985) Severe storm disturbances and reversal of community structure in a southern California kelp forest. Mar Biol 84:287-294

Ebert TA, Schroeter SC, Dixon JD (1991) Studies of feasibility of sea urchin enhancement in California. Final Technical Report to the California Department of Fish and Game (FG9310) dated 30 June 1991. Sacramento

Ebert TA, Schroeter SC, Dixon JD, Kalvass P (1994) Settlement patterns of red and purple sea urchins (Strongylocentrotus franciscanus and $S$. purpuratus) in California, USA. Mar Ecol Prog Ser 111:41-52

Frank PW (1965) The biodemography of an intertidal snail population. Ecology 46:831-844

Gaines S, Roughgarden J (1987) Fish in offshore kelp forests affect recruitment to intertidal barnacle populations. Science 235:479-480

Harrold C, Lisin S, Light KH, Tudor S (1991) Isolating settlement from recruitment of sea urchıns. J exp mar Biol Ecol $147: 81-94$

Harrold C, Reed DC (1985) Food availability, sea urchin grazing, and kelp forest community structure. Ecology 66: $1160-1169$

Hatton H (1938) Essais de bionomie explicative sur quelques espèces intercotidales d'algues et d'animaux. Ann Inst Océanogr, Monaco 17:241-348

Jackson GA, Winant CW (1983) Effects of a kelp forest on coastal currents. Cont Shelf Res 2:75-80

Lang C, Mann KH (1976) Changes in sea urchin populations after the destruction of kelp beds. Mar Biol 36:321-326

Lawrence JM (1975) On the relationship between marine plants and sea urchins. Oceanogr Mar Biol A Rev 13: $213-286$

Loosanoff VL (1964) Variation in time and intensity of setting of the starfish, Asterias forbesi, in Long Island Sound during a twenty-five year period. Biol Bull 126:423-439

Mattison JE. Trent JD, Shanks AL, Akin TB, Pearse JS (1977) Movement and feeding activity of red sea urchins (Strongylocentrotus franciscanus) adjacent to a kelp forest. Mar Biol 39:25-30

Paine RT (1974) Intertidal community structure: experimental studies on the relationship between a dominant competitor and its principal predator. Oecologia 15:93-120

Pearse JS, Clark ME, Leighton DL, Mitchell CT, North WJ (1970) Final report, Marine waste disposal and sea urchin ecology. In: North WJ (ed) Kelp habitat improvement project, annual report 1 July 1969-30 June 1970. WM Keck Laboratory of Environmental Health Engineering, California Instifute of Technology, Pasadena

Pearse JS, Hines AH (1987) Long-term population dynamics of sea urchins in a central California kelp forest: rare recruitment and rapid decline. Mar Ecol Prog Ser 39:275-283

Rankın J (1993) Settlement of Strongylocentrotus spp. across a sea urchin barren-kelp bed boundary. MSc thesis, University of San Diego

Raymond BG. Scheibling RE (1987) Recruitment and growth of the sea urchin Strongylocentrotus droebachiensis (Müller) following mass mortalities off Nova Scotia, Canada. J exp mar Bio! Ecol 108:31-54

Roughgarden J, Gaines S, Possingham H (1988) Recruitment dynamics in complex life cycles. Science 241: $1460-1466$

Rowley RJ (1989) Settlement and recruitment of sea urchins (Strongylocentrotus spp.) in a sea-urchin barren ground and a kelp bed: are populations regulated by settlement or post-settlement processes? Mar Biol 100:485-494 
Schroeter SC, Dixon J, Kastendiek J (1981) Effects of the starfish Patiria miniata on the distribution of the sea urchin Lytechinus anamesus in a southern California kelp forest. Oecologia 56:141-147

Strathmann MF (1987) Reproduction and development of marine invertebrates of the northern Pacific coast. Data

This article was submitted to the editor and methods for the study of eggs, embryos, and larvae. University of Washington Press, Seattle

Tegner MJ, Dayton PK (1981) Population structure, recruitment and mortality of two sea urchins (Strongylocentrotus franciscanus and S. purpuratus) in a kelp forest. Mar Ecol Prog Ser 5:255-268

Manuscript first received: January 24, 1995 Revised version accepted: September 27, 1995 